\title{
アスペクタムによる大気電界変動の解析 風に伴う大気電界の瞬時変動信号の検出一
}

\author{
正 員 大久保 寛* 非会員 千田 正志* \\ 正員竹内 伸直 ${ }^{*}$
}

Analysis of Atmospheric Electric Field Variation Signals using Aspectum of the Digital Natural Observation Method

-Detection of Instantaneous Variation of Atmospheric Electric Field with Wind-

Kan Okubo*, Member, Masashi Chida*, Non-member, Nobunao Takeuchi*, Member

\begin{abstract}
As the atmospheric electric field always fluctuates its observed waveforms are very complicated. It is important to detect the characteristic variation from the observed signals and find out its cause. The natural observation method is adequate to analyze such non-periodic signals as the atmospheric electric field signals. In this method the aspectum is proposed as the quantity to estimate the instantaneous power. In this study signal processing by the aspectum was applied to signals of atmospheric electric field variation. It was clarified that there exists the strong correlation between the instantaneous fluctuation of atmospheric electric field and the wind speed in the convenient meteorological environment.
\end{abstract}

キーワード：ディジタル自然観測法，アスペクタム，風速，大気電界，大気イオン

Keywords: digital natural observation method, aspectum, wind speed, atmospheric electric field, atmospheric ion

\section{1. まえがき}

大気電界は,樣々な要因によって絶えず変動するため, 光 の観測信号は非常に複雑になる。この場合，樣々な要因に よって複雑に变化する大気電界信号から特徽的な変動成分 を検出するための信号処理が重要となる。すなわち，大気 電界変動を明確に識別することで, 現在までに確認するこ とができていない信号を特定できる可能性がある。

大気電界の信号は, 雷雲や雨, 大気中のイオンの振舞い 及び常時発生している電離層から地表面への下向きの電界 変化などの樣々な要因によって絶えず変動している ${ }^{(1) \sim(3) 。 ~}$ 特に, 雷雲や雨に大きく影響されるが, 快晴時においても， 気象条件などにより何らかの変動が発生している ${ }^{(4)}$ 。大気 は厳密には絶縁体ではなく，わずかではあるが導電率を持 つが，この導電率の発生原因は主に大気イオンと呼ばれる 正負に帯電した粒子である。晴天時の大気電界は雷雲など の影響が少ないため, 他の要因に比べて大気イオンの影響 が大きく現れる。

大気イオンは, 一般にエアロゾルと呼ばれる粒子が帯電

* 秋田県立大学システム科学技術学部

厂 015-0055 秋田県本荘市土谷字海老ノ口 84-4

Akita Prefectural University

84-4 Tsuchiya-Ebinokuchi, Honjo, Akita 015-0055
した状態である。したがって , このエアロゾルの分布が大 気中の電荷分布に大きく影響する。また, エアロゾルは, 大 気の気象条件によって密度や分布か変動するため, 大気イ オンの変動, 言い換えれば, 大気電界の変動は気象条件に 大きく依存することが考えられる ${ }^{(5) \sim(8)}$ 。これまでも，気 象条件によって, 大気電界信号の振幅力変動することは経 験的には知られており，観測報告もある ${ }^{(1)(3) \sim(5) 。 し か し ， ~}$ これまでの報告は海洋型と陸地型の相違，日変化及び降雨 の影響などの長期間にわたる变動に関するものであり，数 秒以下の瞬時的な変動については定量的な解析を行った例 はほとんどない。

竹内らは, 晴天・微風時大気電界微小变動の観測を高い 建物の屋上で行い, 微風時に大気電界に数分の特徵的な微 小変動が存在することを報告した ${ }^{(5)}$ 。この変動は, 数百 $\mathrm{m}$ 程度の規模と考えられ，時間とともに観測点間を移動する。 竹内らはこの变動に対して大気循環による大気自体の变動 が, 観測点上空の大気電界変動の原因になるというモデル を提案している。しかし，二の観測報告は気象庁風力階級 2 か 3 の微風時の観測に対して行われたものであり，風速 が弚れ以上の場合については検討が行われていない。また， 地表面付近での大気電界変動と風との関連などについても 明らかにされていない。

図 1 に大気中の風の樣子について模式図を示す。同図よ 


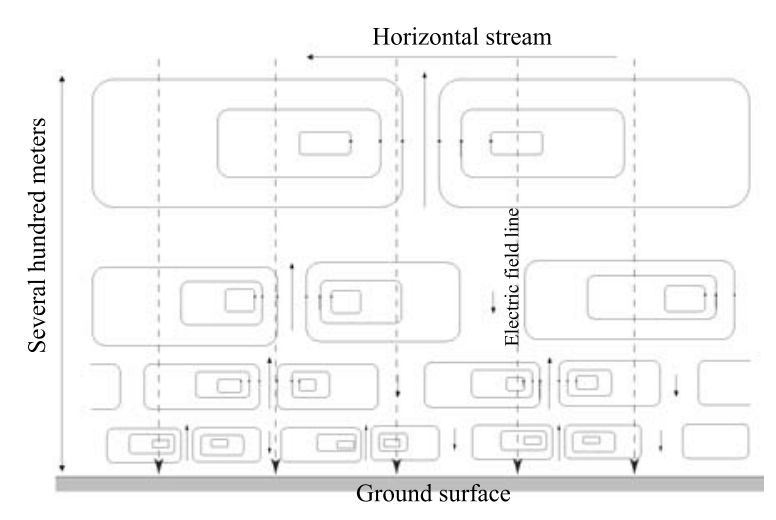

図 1 大気渦の模式図

Fig. 1. Sketch of atmospheric eddies.

り，地表面から数百 $\mathrm{m}$ の範囲では大気中に渦が形成される

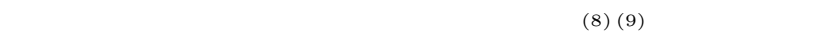
面近くでは, ほぼ乱流となることが知られている。エアロ ゾルは体積及び質量を持った粒子であるから，大気中の風 によって密度や分布か変動する。したがって, 大気中の電 荷分布も風の影響を受け, 大気中の風と大気電界の変動に 何らかの関連性が考えられる。すなわち，降水粒子などの 影響がほとんど無い場合，大気電界は全ての高さにおける 風の動きの影響を受けるため光の変動は非常に複雑となる。

ここで, 風によって大気電界か変動すると考えると，こ の変動は, 周期的な変動とはならず, 風の変動に伴う瞬時 的な変動であることが予想される。すなわち，この大気電 界の変動は, 一定の周期て変動しているものではない。

一方, このような周期性を持たない瞬時的な変動信号の 解析法として,近年, 自然観測法理論が注目されている。自 然観測法理論 ${ }^{(10) \sim(17)}$ は，信号の瞬時的な変化に着目した 全く新しい信号解析法である。すなわち, フーリ工解析法 や最大エントロピー法は信号を周波数に分解する解析法 ${ }^{(18)}$ であるのに対して, 自然観測法では時々刻々変化する信号波 形の傾き (微分) を示す係数に分解する信号解析法である。 これまでに非定常な瞬時変動成分を検出する場合に，本解 析法か非常に有効な手法であることが示されている(12)(13)。 特に , アスペクタムは時系列信号の瞬時パワーの新しい評 価量として有効である ${ }^{(11)(13)}$ 。

大気電界の観測は比較的容易であるために，しばしば自 然現象の電磁気的観測に用いられるが，大気電界の瞬時的 な変動については，これまで十分に解析が行われていると は言えず, 大気電界の変動について十分に議論を行うため には, この瞬時変動成分について検討し，発生要因を明確 にする必要がある。

本研究では, 秋田県の本荘観測地点において大型平板ア ンテナを用いて大気電界の観測を行っている。竹内らは， フィールドミル電界計と平板アンテナの比較実験を行い， 数分より速い変動についての観測に本研究と同樣の平板電 極観測方式が適していることを報告している ${ }^{(5)}$ 。

本論文では，この大気電界の観測信号にアスペクタムに
よる信号解析を適用し, 大気電界变動信号の瞬時的な解析 を行う。また , 大型平板アンテナを用いた大気電界の観測 と同時に超音波風速計による風速の観測を行うことで, 風 に関連する大気電界の変動について検討する。

\section{2. 自然観測法理論}

自然観測法理論は, 近年, 信号解析の新しい手法として 飯島泰蔵東工大名誉教授により提唱されている波形の瞬時 的な変化に着目した新しい信号解析法理論である ${ }^{(10)(11)}$ 。 文献 (10)において連続系の自然観測法理論が述べられてお り，文献(11)では文献 (10)の内容を離散系に適用したディ ジタル自然観測法についての理論が展開されている。自然 観測法理論の本質は時系列信号の瞬時特性を把握すること にある。以下にディジタル自然観測法について概略を示す。

今，観測された任意のディジタル時系列信号を $f(n)$ と した時，恒等作用素 $I$, 遅延作用素 $D$ を兴れ下のよ うに定義する。

$$
\begin{aligned}
I f(n) & =f(n) \ldots \ldots \ldots \ldots \ldots \ldots \ldots \ldots \ldots \ldots \ldots \\
D f(n) & =f(n-1) \ldots \ldots \ldots \ldots \ldots \ldots \ldots
\end{aligned}
$$

ここで，これらの作用素を用いて

$$
\begin{aligned}
\Gamma & =(1-\lambda) I+\lambda D \ldots \ldots \ldots \ldots \ldots \ldots \ldots \ldots \ldots \ldots \ldots \ldots \ldots \ldots \\
\Lambda & =\lambda I-\lambda D \ldots \ldots \ldots \ldots \ldots \ldots
\end{aligned}
$$

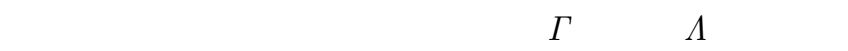
れ原始作用素および随伴原始作用素と呼ばれている。入は $0<\lambda<1$ を満たす重み係数である。ここで， $M$ を位数， $m$ を次数， $\Lambda$ を $m$ 回作用させた作用素を $\Lambda^{m}$ として，

$$
X_{m}^{(M)}=\Gamma^{M-m} \Lambda^{m} \quad(m=0,1, \cdots, M) \cdots
$$

なる作用素を新たに考え，

$$
n_{m}^{(M)}(n)=X_{m}^{(M)} f(n) \cdots
$$

という新たな時系列信号を定義する。 $n_{m}^{(M)}(n)$ は時系列信 号 $f(n)$ に対応する基本観測値と呼ばれる $M$ 位の時系列信 号となり，時刻 $n$ における観測波形の瞬時的な変化を示し たものである。式 (5) で示される作用素をフィルタとみな した場合，観測波形 $f(n)$ に作用させることで，観測波形 の瞬時的な変化を示す時系列信号 $n_{m}^{(M)}(n)$ を与える $X_{m}^{(M)}$ を $M$ 位 $m$ 次基本観測フィルタと呼ぶ。

以下に, 式 (6) より得られる基本観測値の導出式を示す。

$$
\begin{aligned}
n_{m}^{(M)}(n)= & \sum_{l=0}^{M}\left(\begin{array}{c}
M \\
l
\end{array}\right)(1-\lambda)^{M-l} \lambda^{l} \\
& \left\{\left(\frac{\lambda}{1-\lambda}\right)^{m} k^{(M)}(m, l)\right\} f(n-l) \\
& (m=0,1, \cdots, M) \cdots \cdots(
\end{aligned}
$$

ただし， 


$$
\begin{array}{r}
k^{(M)}(m, l) \\
=\frac{1}{\left(\begin{array}{c}
M \\
l
\end{array}\right)} \sum_{r=0}^{l}(-1)^{r}\left(\begin{array}{c}
m \\
r
\end{array}\right)\left(\begin{array}{c}
M-m \\
l-r
\end{array}\right)\left(\frac{1-\lambda}{\lambda}\right)^{r} \\
(l=0,1, \cdots, M) \cdots \cdots(8)
\end{array}
$$

$\lambda$ は $0<\lambda<1$ を満たす係数であるが, 標準値は $1 / 2$ と されている(11)。ここで, $\left(\begin{array}{c}M \\ l\end{array}\right)$ は 2 項係数である。

また，逆に $M$ 位の時系列信号 $n_{m}^{(M)}(n)$ から

$$
f(n)=\sum_{m=0}^{M}\left(\begin{array}{l}
M \\
m
\end{array}\right) n_{m}^{(M)}(n)
$$

なる式によって，完全に元の時系列信号 $f(n)$ に復元する ことができる。また，式 (6) および式 (9) を併せて自然観 測変換と呼ばれている。

〈2 1〉アスペクタム自然観測法理論において, 式 (10) に示される量をアスペクタム ${ }^{(11)}$ と呼ぶ。ただし , $\left|n_{m}^{(M)}(n)\right|$ は $n_{m}^{(M)}(n)$ の絶対値を示している。

$$
A_{m}^{(M)}(n)=\sqrt{\left(\begin{array}{l}
M \\
m
\end{array}\right)\left(\frac{1-\lambda}{\lambda}\right)^{m}}\left|n_{m}^{(M)}(n)\right| \cdots
$$

また,式 (11) に示されるように, 瞬時ノルム ${ }^{(10)(11)} の$ 2 乗値 $\|f\|_{n}^{2}$ は, アスペクタムの 2 乗値 $\left\{A_{m}^{(M)}(n)\right\}^{2}$ によっ て分解表示が可能である。

$$
\|f\|_{n}^{2}=\sum_{m=0}^{M}\left\{A_{m}^{(M)}(n)\right\}^{2} \ldots \ldots \ldots \ldots \ldots \ldots
$$

これは,アスペクタムの総和か瞬時の全パワーとなること を示しており，したがって，アスペクタムは次数 $m$ におけ る時系列信号の瞬時のパワーを表す量となる。

\section{3. 観測システム}

本研究で大気電界の変動信号の観測を行っているのは, 秋田県本荘市の秋田県立大学システム科学技術学部構内に ある本荘観測地点である。図 2 に本荘観測地点を示す。観 測地点には, 大気電界変動信号の観測を高感度で行うため に，図 3 に示すような大型平板アンテナを製作し設置して いる。このアンテナは, アルミニウム製の 1 辺 $4 \mathrm{~m}$ の正方 形の大型平板アンテナであり，地上高約 $4 \mathrm{~m}$ に絶縁体（碍 子）によって固定されている。

また , アンテナから離れた場所に , 観測信号を記録する データ処理システムを収納するための観測小屋を設置し， 観測信号は同軸ヶーブルにより引き込んでいる。信号はサ ンプリング時間 $0.1 \mathrm{~s}$ の時間分解能を持つデータ記録装置 (TOADKK 社製 DR-1021) で常時記録されている。観測 された信号は記録装置によって AD 変換され，ディジタル データとして蓄積される。現在，GPS を用いて時刻精度 $1 \mathrm{~ms}$ を実現している。

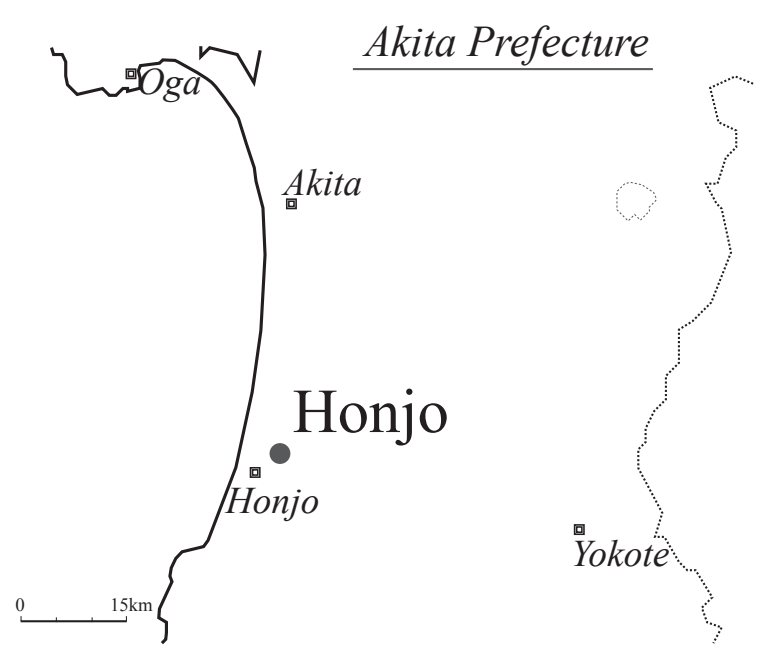

图 2 本荘観測地点の位置

Fig. 2. Location of Honjo observation point.

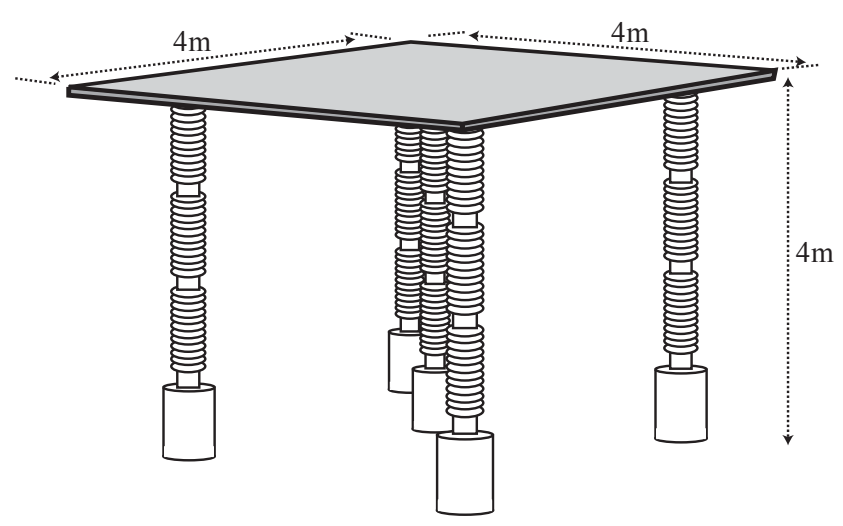

图 3 大気電界観測用大型平板アンテナ

Fig. 3. Large plate antenna.

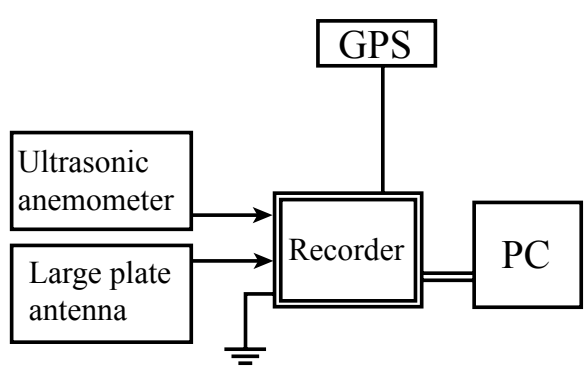

図 4 観測システムのブロック図

Fig. 4. Block diagram of observation system.

さらに，同観測地点にYOUNG 社製の超音波風速計を 設置し，DR-1021 記録装置を使用して，大気電界と地表 面付近の風速の同時観測を実現している。この超音波風速 計は, アナログ出力端子を持っており, 最大出力電圧 $4 \mathrm{~V}$ で, 風速を測定できる。本研究では, $20 \mathrm{~m} / \mathrm{s}$ の風速の場合 に $4 \mathrm{~V}$ が出力されるように設定されおり，本システムでは 風速 $20 \mathrm{~m} / \mathrm{s}$ までを記録できる。また，超音波風速計の最大 時間分解能は， $0.03125 \mathrm{~s}$ である。超音波風速計は従来のプ ロペラ式のものに比べ, 時間応答特性に優れており風速に 
対する時間遅れはほとんどない。图 4 に観測システムのブ ロック図を示す。

\section{4. 風速変動に関連する大気電界信号の解析}

〈4 1〉大気電界変動信号への瞬時パワー解析 本節 では，3で示した観測システムによって実際に観測された 大気電界変動信号にアスペクタムを適用し, 瞬時パワーを 用いて解析を行う。

大型平板アンテナ及びDR-1021 で記録された晴天時の大 気電界の観測波形を图 5 に示す。ただし, 記録装置のサンプ リング時間は $0.1 \mathrm{~s}$ である。この図には大気電界か顕著な変

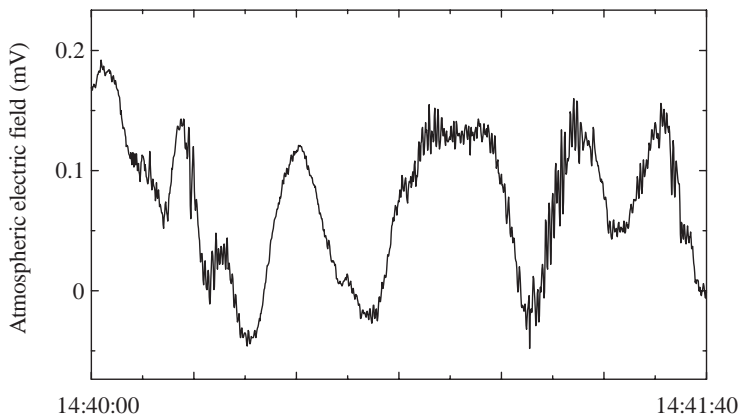

図 5 大気電界変動の観測波形 (2001 年 10 月 14 日 14:40:00 から 100 秒間)

Fig. 5. Observed waveform of atmospheric electric field.

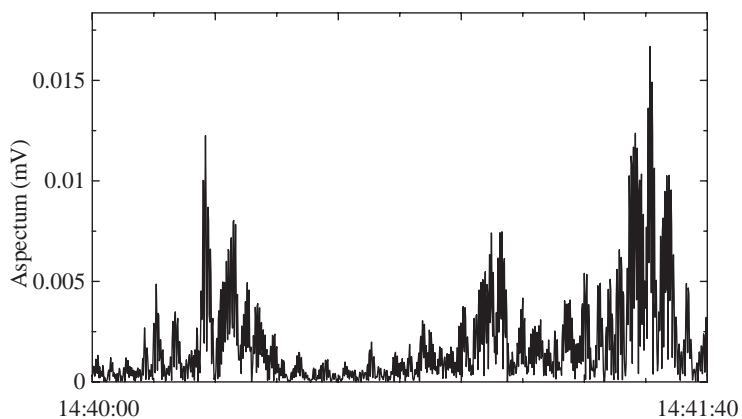

図 6 図 5 の大気電界変動波形のアスペクタム $(M=20, m=4, \lambda=1 / 2)$

Fig. 6. Aspectum of atmospheric electric field.

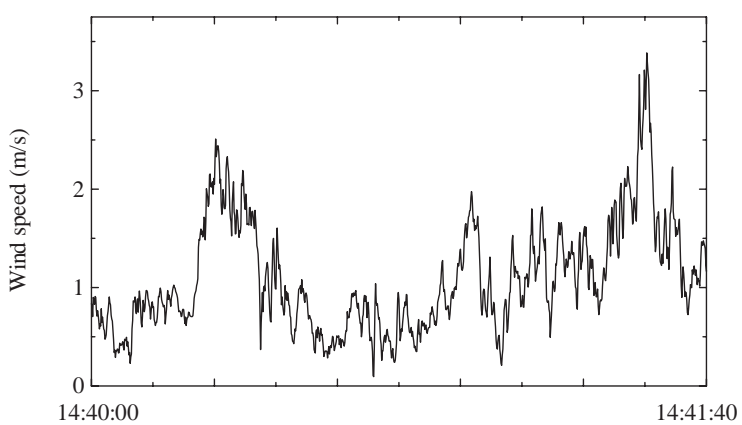

図 7 風速変動の観測波形 (2001 年 10 月 14 日 14:40:00 から 100 秒間)

Fig. 7. Observed waveform of wind speed.
動を示していた 2001 年 10 月 14 日 14:40:00 から 14:41:40 の 100 秒間の波形が示されている。また，図 5 の波形に アスペクタムを適用した波形を図 6 に示す。ここで，アス ペクタムを適用する際のパラメータは $M=20, m=4$, $\lambda=1 / 2$ としている(11) (13)(15)。また , アスペクタムにつ いてはフィルタの遅れを補正して, 左に $1 \mathrm{~s}$ だけシフトして 表示している。図 5 より，数十秒周期の変動成分とともに， 細かい両極性の微小パルス信号か観測されているのがわか るが, 図 6 のアスペクタムによってこの微小変動が瞬時パ ワーとして検出されている。

超音波風速計によって観測された風速変動信号を図 7 に 示す。ここで, 図 6 と図 7 を比較すると, 風速が大きな值 を示す時間にアスペクタムが大きな值となっていることが わかる。すなわち，両者の変動は非常によく一致しており，

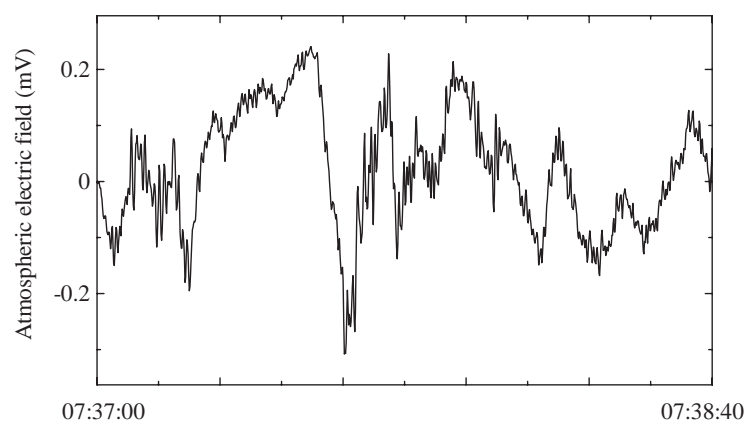

(a)

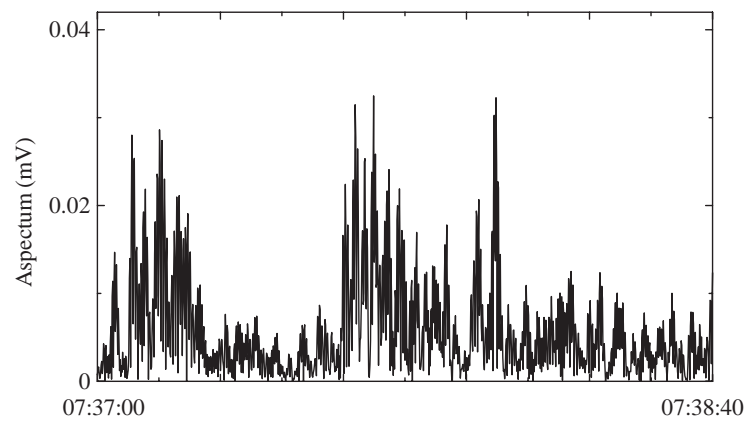

(b)

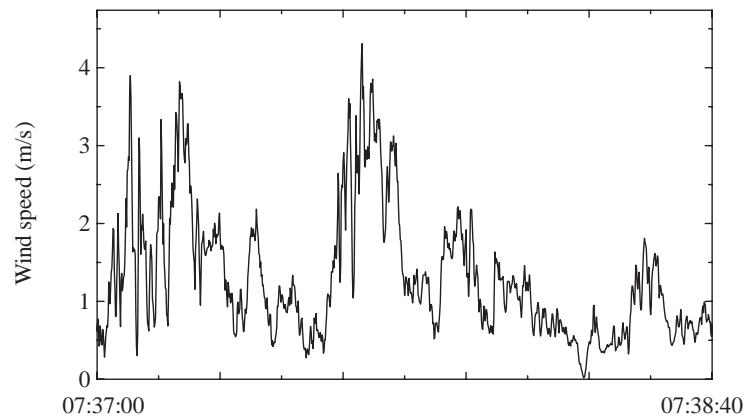

(c)

図 8 観測波形とアスペクタム ( (a) 大気電界 , （b) 大気電界のアスペクタム，(c) 風速) (2001 年 10 月 14 日 07:37:00 から 100 秒間)

Fig. 8. (a)Observed waveform of atmospheric electric field, (b)aspectum of atmospheric electric field and (c)observed waveform of wind speed. 
大気電界のアスペクタムと風速には非常に強い相関がある と考えられる。

さらに , 同日の他の時間帯についても検討を行った。图 8 及び図 9 に光れ光れ 2001 年 10 月 14 日 07:37:00 から 100 秒間及び 12:55:00 から 100 秒間の波形を示す。ただし，両 図において (a) 大気電界，(b) 大気電界のアスペクタム及 び (c) 風速変動としている。両図とも, 大気電界のアスペ クタムと風速変動はよく一致している樣子がわかる。これ より，時間帯に関係なく，大気電界のアスペクタムと風速 変動は強い相関関係を持つことを示すことができた。

図 5 , 図 8 及び図 9 は風速が数 $\mathrm{m}$ の場合であるが, さ らに，風速が $10 \mathrm{~m}$ を超える場合について解析を行った。図 10 に 2001 年 10 月 10 日 19:30:00 から 100 秒間の波形を 示す。ただし，(a) 大気電界，(b) 大気電界のアスペクタム 及び (c) 風速変動としている。同図より, 風速が $10 \mathrm{~m}$ を超

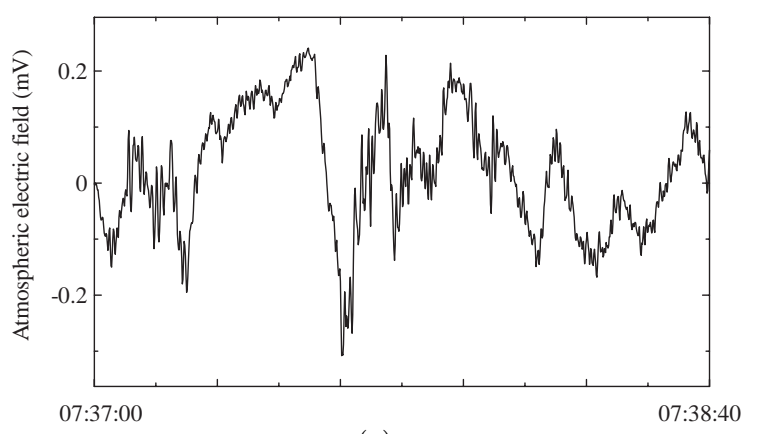

(a)

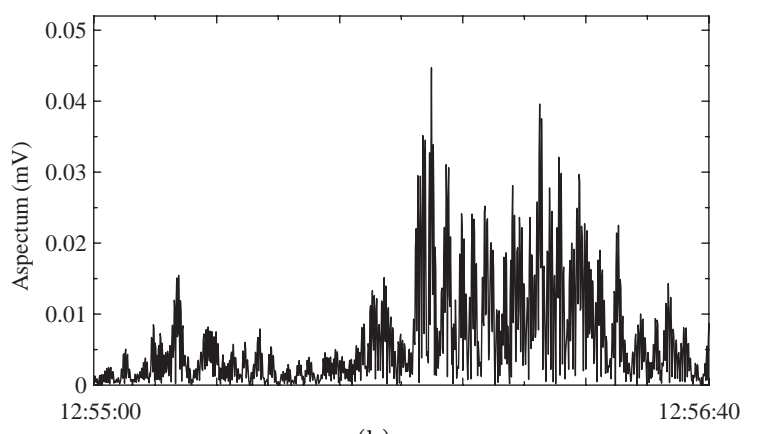

(b)

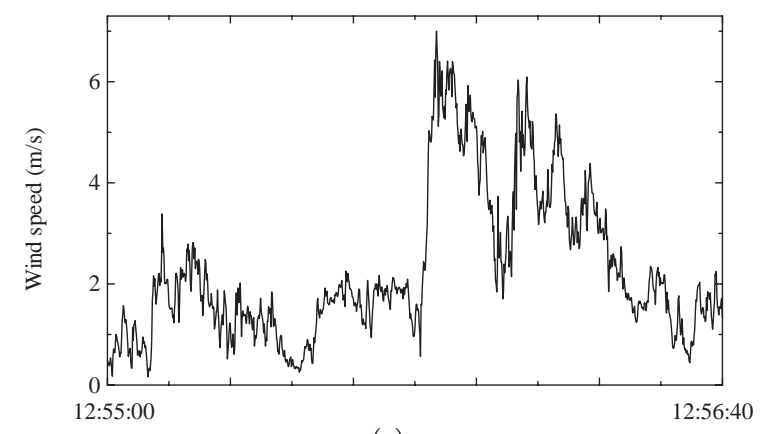

(c)

図 9 観測波形とアスペクタム ( (a) 大気電界 , (b) 大気電界のアスペクタム, (c) 風速) (2001 年 10 月 14 日 12:55:00 から 100 秒間)

Fig. 9. (a)Observed waveform of atmospheric electric field, (b)aspectum of atmospheric electric field and (c)observed waveform of wind speed.
える場合についても両者はよく一致している。

次に，両者の相関を定量的に示すために，両者の相互相関 係数を求めた。図 11 に 2001 年 10 月 14 日の 00:20:00 から 00:50:00 までの 30 分間の風速波形に移動平均処理 (19) (20) を行った波形を示す。今，記録装置のサンプリング時間は $0.1 \mathrm{~s}$ とており，同図には 18000 点のデータを示している。 アスペクタムは, 細かい信号波形となっており， $0.1 \mathrm{~s}$ 程度 の細かい変動については風速変動とあまり一致してない。 乥こで, 以下では, $0.5 \mathrm{~s}$ 程度の変動の相関を検討すること として, 移動平均は各時間における前後 2 点のデータ, す なわち， $0.5 \mathrm{~s}$ 間のデータの平均として求めている。また， 2001 年 10 月 14 日の 00:30:00 から 00:40:00 までの 10 分 間の大気電界のアスペクタムに図 11 と同樣に，移動平均 処理した波形を図 12 に示す。

次に, 図 11 と図 12 の相互相関係数を計算した結果を図

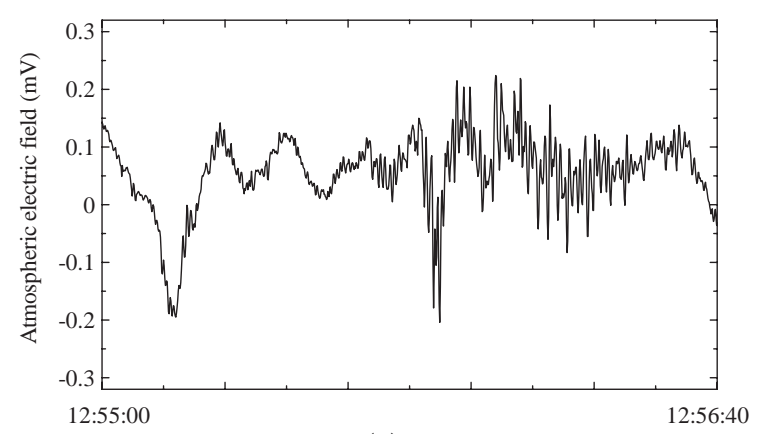

(a)

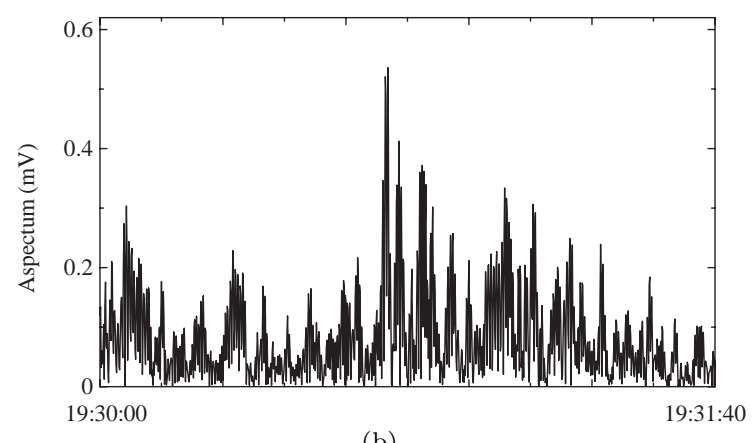

(b)

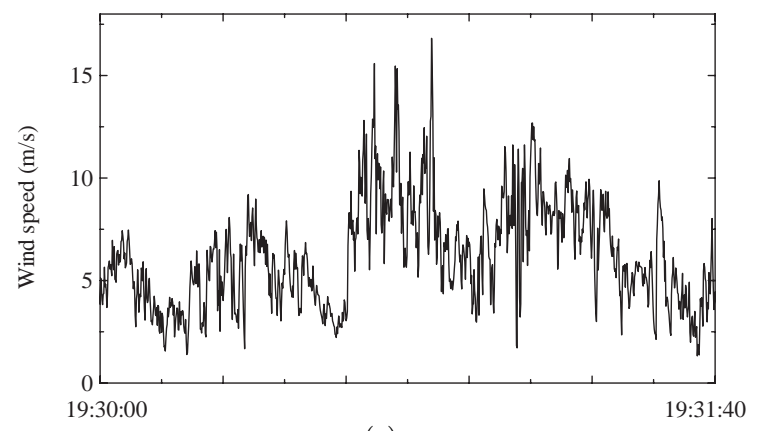

(c)

図 10 観測波形とアスペクタム ( (a) 大気電界 , (b) 大気電界のアスペクタム, (c) 風速) (2001 年 10 月 10 日 19:30:00 から 100 秒間)

Fig. 10. (a)Observed waveform of atmospheric electric field, (b)aspectum of atmospheric electric field and (c)observed waveform of wind speed. 


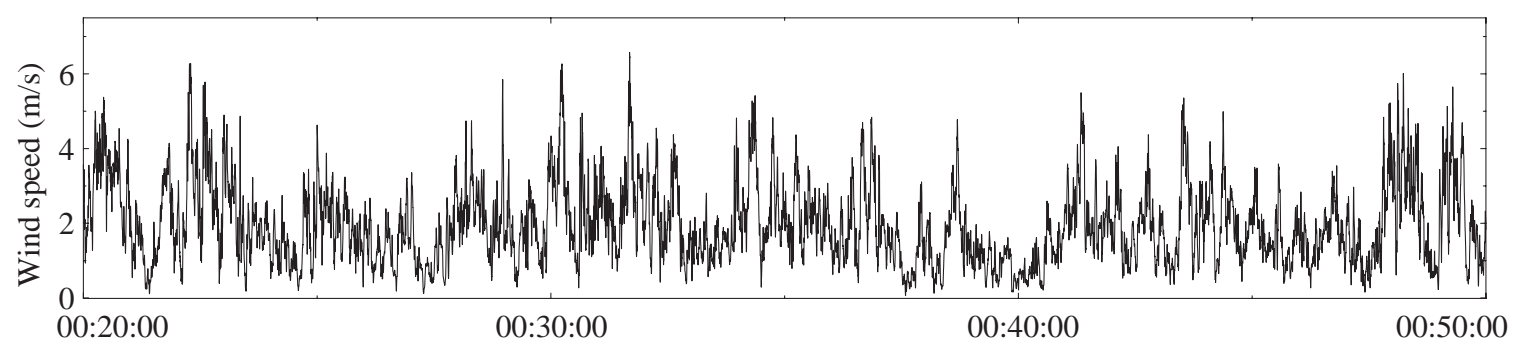

図 11 移動平均処理した風速変動 (2001 年 10 月 14 日 00:20:00 から 30 分間)

Fig. 11. Observed waveform of wind speed with moving average.

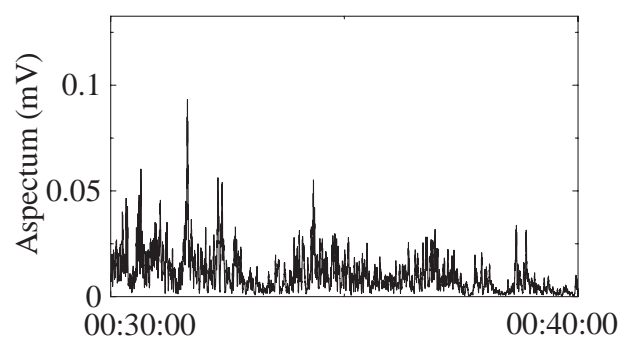

図 12 移動平均処理した大気電界のアスペクタム (2001 年 10 月 14日 00:30:00 から 10 分間)

Fig. 12. Aspectum of atmospheric electric field with moving average.

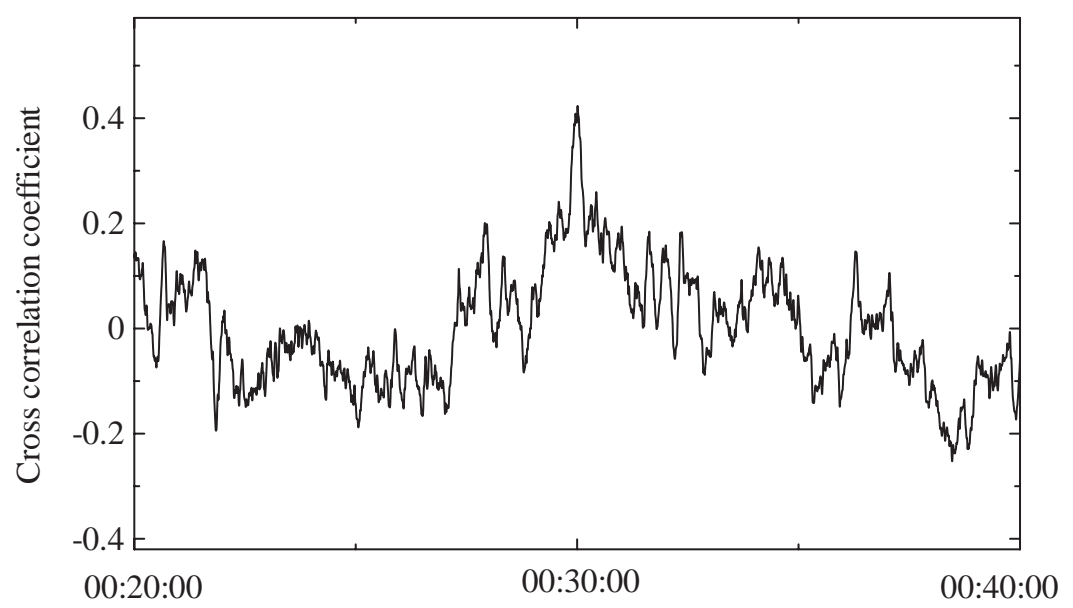

図 13 大気電界のアスペクタムと風速の相互相関係数

Fig. 13. Cross correlation coefficient between aspectum of atmospheric electric field with moving average(fig.11) and wind speed with moving average(fig.12).

13 に示す。ただし，計算方法としては，图 11 の移動平均 処理した波形に図 12 の移動平均処理した波形を 1 点ずつ シフトして产の点での相互相関係数を算出している。同图 より，00:30:00 の近傍て鋭いピークとなっており，大気電 界のアスペクタムと風速変動の相関関係が定量的に示され ている。したがって，大気電界のアスペクタムの振幅は風 速の大きさに対応しているといえる。また，相関係数の最 大ピークの時間は, 厳密には, 00:30:00より右に $0.7 \mathrm{~s}$ だけ ずれていたが，これはアスペクタムが非常に複雑な信号と なるために生じたと考えられる。したがって，この結果が， 風速変動に先行して大気電界微小変動が存在する可能性を 示唆するものではない。さらに，他の時間帯についても同
樣に相互相関係数を計算することにより，図 13 と同樣に大 気電界のアスペクタムと風速変動に相関があることを明ら かにすることができた。

晴天時の大気電界は大気中のエアロゾルの挙動に大きく 影響を受ける。したがって，風速によって大気中のエアロ ゾルの分布か変動し, 光の挙動が大気電界の微小变動に影 響をもたらすものと推測される。ただし, 現段階では, 他 の気象パラメータなどのデータがないため, 詳細なモデル の提案はできていない。今後, さらに他の気象パラメータ との比較解析を行うことで, 複雑な大気電界変動の解明に つながることが期待される。 


\section{5. むすび}

本論文では, 大気電界変動と気象パラメータの相関につ いての基礎的な研究として，アスペクタムによって晴天時 大気電界変動の解析を行った。光の結果, 大気電界瞬時変 動と風速が密接に関連しており, 大気電界の微小変動の振 幅は地表面近傍の風速の振幅に対応していることを明らか にした。

これより，例えば，風速の大きさを計測すると同時に，平 板アンテナによる大気電界微小変動を観測して, 気象環境 のモニタリングシステムを構築できる可能性が考えられる。 ただし，大気電界は，雨天時には雨の中に含まれる電荷の 影響を強く受けるため, 弚の変動はさらに複雑になる。本 システムによる環境モニタリングの実用化に向けては，今 後さらに樣々な気象パラメータ及び気象条件について検討 を行う必要があると考えられる。

ディジタル自然観測法は，従来の手法とは異なり時刻時 刻の瞬時的な変動を評価する信号解析法であり，瞬時的な 変動の特徵を新しい視点で捉えることが可能となる。これ まで，アスペクタムを用いた信号解析については，十分な 議論が行われているとは言えず，今後，さらに検討を行う 必要があるが, 本研究は, 自然環境下の電磁変動信号に対 するアスペクタムを用いた瞬時解析法の有効性を示したも のと考えられる。

(平成 16 年 4 月 26 日受付, 平成 16 年 11 月 15 日再受付)

文献

（1）北川信一郎編著：大気電気学, 東海大学出版会 (1996)

（2）日本大気電気学会 : 大気電気学概論，コロナ社 (2003)

（3）畠山久尚・川野 實 : 気象電気学，岩波全書 (1955)

（4）小川俊夫：「地球をとりまく大気電場」, 静電気学誌, Vol.6, No.5, pp.383-394 (1981)

( 5 ) K. Narita, N. Takeuchi, N. Chubachi, and N. Honma: "Small Variational Signals of Atmospheric Electric Field under Fair Weather", T. IEE Japan, Vol.117-C, No.10, pp.1450-1455 (1997-10) (In Japanese)

成田憲一・竹内伸直 $\cdot$ 中鉢憲賢・本間規泰 : $\ulcorner$ 晴天時大気電界微小変 動の観測」, 電学論 $(\mathrm{C}), \mathbf{1 1 7}, 10$, pp.1450-1455, (1997-10)

（6）廣田 勇, グローバル気象学, 東京大学出版会 (1992)

（7）竹内清秀: 風の気象学, 東京大学出版会 (1997)

（8）近藤純正 : 地表面に近い大気の科学, 東京大学出版会 (2000)

( 9 ) R. Reiter, Phenomena in atmospheric environmental electricity, ELSEVIER (1992)

(10) 飯島泰蔵：自然観測法の理論，森北出版 (2000)

(11) 飯島泰蔵 : ディジタル自然観測法, 森北出版 (2001)

(12) K. Okubo and N. Takeuchi: "An Examination on Detection of Minute Fluctuation Signal by Theory of Natural Observation Method", T. IEE Japan, Vol. 123-A, No. 7, pp.644-650 (2003-7) (In Japanese)

大久保寛・竹内伸直 : $\ulcorner$ 自然観測法理論による微小変動信号の検出に ついての検討」, 電学論 $(\mathrm{A}), \mathbf{1 2 3}, 7, \mathrm{pp} .644-650$ (2003-7)

(13) K. Okubo and N. Takeuchi: "Evaluation of Instantaneous Power by Aspectum on Theory of Natural Observation Method", T. IEE Japan, Vol. 124-A, No. 5, (2004-5) (In Japanese)

大久保寛・竹内伸直 : $\ulcorner$ 自然観測法理論におけるアスペクタムを用い た瞬時的なパワーの評価」, 電学論 $(\mathrm{A}), \mathbf{1 2 4}, 5,(2004-5)$

(14) K. Okubo and N. Takeuchi: "Characteristic Time Determination Method of Transient Electromagnetic Field Signal by Theory of Natural Observation Method", T. ICICE Japan,
Vol. J86-B, No.11, (2003-11) (In Japanese)

大久保寛・竹内伸直 : $\ulcorner$ 自然観測法理論による過渡電磁界信号の特性 時間決定法」, 信学論 (B) , J86-B，9，pp.1731-1738 (2003-9)

(15) K. Okubo and N. Takeuchi: "Examination on Determination of Order $M$ in Detecting the Characteristic Time by Digital Natural Observation Method", T. ICICE Japan, Vol. J87-A, No.3, pp.409-412 (2004-3) (In Japanese)

大久保寛・竹内伸直 :「ディジタル自然観測法により特性時間を検出 する場合の位数 $\mathrm{M}$ の決定に関する検討」, 信学論 (A) , J87-A, 3, (2004-3)

(16) T. Iijima: "Fundametal Theory of Natural Observation Transformation", T. ICICE Japan, Vol. J76-A, No.11, pp.1620-1626 (1993-11) (In Japanese)

飯島泰蔵 : 「自然観測変換の基礎理論」, 信学論 (A)，J76-A，11， pp.1620-1626 (1993-11)

(17) M. Iwaki and T. Iijima: "Natual Observation Method for Discrete-Time Waveforms", T. ICICE Japan, Vol. J79-A, No. 3, pp.728-735 (1996-3) (In Japanese)

岩城 護・飯島泰蔵：「離散時間波形に対する自然観測法について」, 信学論 (A)，J79-A，3, pp.728-735 (1996-3)

(18) 金井 浩：音・振動のスペクトル解析，コロナ社 (1999)

(19) 萩原幸男·系田千鶴 : 地球システムのデータ解析, 朝倉書店 (2001)

(20) 南 茂夫 : 科学計測のための波形データ処理, CQ 出版社 (1986)

大久保 寛 (正員) 1976 年 5 月 2 日生。1999 年 3 月東北

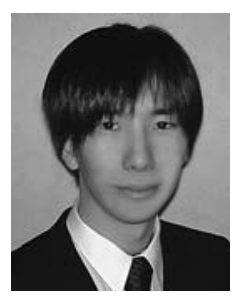
大学工学部電気工学科卒業。2001 年 3 月同大大 学院工学研究科博士課程前期課程修了。2004 年 3 月同工学研究科博士課程後期課程修了。2001 年 4 月より秋田県立大学システム科学技術学部助手。 博士 (工学)。自然界における電磁変動現象の信 号解析・シミュレーションに関する研究, 自然観 測法理論による信号解析法の研究に従事。平成 14 年度電気学会論文発表賞受賞。電子情報通信学会, IEEE 各会員。
千田正志

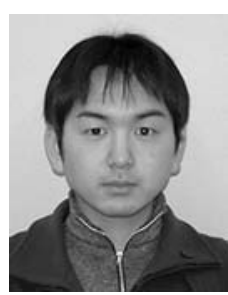

竹 内 伸 直

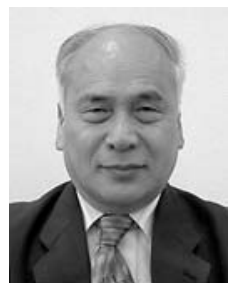

(非会員) 1979 年 10 月 8 日生。2003 年 3 月秋 田県立大学システム科学技術学部電子情報システ 么学科卒業。在学中は自然環境における電磁界観 測の研究に従事。
(正員) 1942 年 4 月 6 日生。1965 年 3 月東北大 学工学部電子工学科卒業。1970 年 3 月同大大学 院工学研究科電気および通信工学専攻博士課程単 位修了。同年 4 月東北大工学部助手, 同助教授を 経て, 現在, 秋田県立大学システム科学技術学部 教授。工学博士。地震, 雷の電磁変動量の計測と 炎の信号解析の研究に従事。大気電気学会会員。 